Агнета ШАШКОВА, orcid.org/0000-0001-8518-2621

аспірантка кафедри теорії та історії мистечтвва Начіональної академії образотворчого мистецтвв та архітектури (Київ, Україна) agneta.shashkova@gmail.com

\title{
ПРОБЛЕМАТИКА АТРИБУЦІЇ ІКОН І. С. ЇЖАКЕВИЧА «ЕВАНГЕЛІСТИ» (ЦЕРКВА ПОКРОВИ ПРЕСВЯТОЇ БОГОРОДИЦІ, ПРІОРКА М. КИЇВ)
}

Статтю присвячено атрибуиії чотирьох ікон із зображенням євангелістів, які походять із центральних Царських воріт іконостасу Церкви Покрови Пресвятої Богородиці (Пріорка м. Київ). Як відомо, ікони з іконостасу були створені у 1943-1945 роках I. Їжакевичем та учнями. Досі науковщі не висували припущень щзодо авторства I. Їжакевича в іконах «Євангелісти» з иентральної частини иього іконостасу. Метою статті є всебічне дослідження иъього питання й аргументування гіпотези про співавторство I. С. Їжакевича та іншого, менш вправного художника при створенні зображень чотирьох євангелістів.

Атрибуція побудована на основі комплексного візуального дослідження: техніко-технологічного й живописно-стилістичного аналізу із залученням макрофотофіксацї та дослідження в інфрачервоному випромінюванні. Допоміжну роль відіграли архівні дослідження та порівняльний аналіз із іконами з подібним зображенням із Свято-Покровської Подільської ичеркви (м. Київ).

Застосування авторських правок визначено нами як відмінну рису іконопису I. Їжакевича в Покровській церкві на Пріориі як у ряді інших ікон храму, так і в зображеннях євангелістів.

3'ясовано особливості творчої співпраці I. С. Їжакевича з іншими художниками у період 1940-1960 рр., по-перше, у виконанні графічних ескізів із зображенням євангелістів (нині зберігаються у ЦДАМЛМ), щзо, як було нами з'ясовано, є підготовчими малюнками до ікон з парусів Свято-Покровського Подільського храму. Так, на основі аналізу техніки виконання було визначено, щя ескіз із образом св. євангеліста Марка, виконаний іншим художником, ймовірно, його учнем Ф. Коновалюком. На основі иъього висунуто припущення щзодо невірного датування ескізів та його уточнення: замість початку ХХ століття - 1940-1960-ті рр.

По-друге, характер співавторства встановлено нами на основі інших ікон з Покровського храму на Пріориі; аналогічним чином висновки щуодо присутності двох авторів у іконах євангелістів здійснено на основі комплексного дослідження та аналізу зображень євангелістів - як характеру підготовчого малюнку, так $і$ самого живописного шару (стилістичних особливостей, колориту, трактовки форми, техніки живопису). Визначено відмінності у побудові композииї̈ та малюнку, у рівні майстерності виконання; виконано аналіз живописної манери як I. Їжакевича, так і невідомого художника - його співавтора.

Результати розвідки стануть корисними для подальших досліджень творчості I. Їжакевича, в тому числі для створення каталогів, щзо включали б атрибутовані твори мистия, які наразі є дуже актуальними.

Ключові слова: творчість І. Їжакевича, іконопис, атрибуція, євангелісти, Покровський храм на Пріориі, Покровський храм на Подолі, співавторство.

\section{PROBLEMS OF ATTRIBUTION OF ICONS 'EVANGELISTS' OF I. S. YIZHAKEVYCH (HOLY MARY POKROVSKY CHURCH, PRIORKA, KYIV)}

This article is devoted to the attribution offour icons representing evangelists which came from central holy gates of the iconostasis in the Holy Mary Pokrovsky Church (Priorka, Kyiv). As is commonly known, icons from the iconostasis were painted by I. Yizhakevych and his students in 1943 to 1945. Scientists have not made assumptions regarding the authorship of I. Yizhakevych in the icons 'Evangelists' from the central part of this iconostasis yet. The purpose of this article is to inquire into this question comprehensively and to argue the hypothesis for cooperation between I. S. Yizhakevych and other less skilful artist when painting four evangelists.

The attribution is based on the overall visual study: technical and technological as well as painting and stylistic analysis involving the macrophotofixation and study in the IR radiation. Archival studies and comparative analysis with the icons having the same image from the St. Pokrovsky Church in Podil (Kyiv) played a supplementary role. 
We have considered the author's corrections to be a specific feature of the icon painting of I. Yizhakevych in the Pokrovsky Church in Priorka in a range of other icons in the church and in pictures of evangelists.

We have also discovered features of the creative cooperation of I. S. Yizhakevych with other artists from 1940 to 1960, firstly, in graphic sketches representing evangelists (now kept in the Central State Archive Museum of Literature and Arts), which are preparatory to icons from the arches of the St. Pokrovsky Church in Podil as discovered by us. For example, based on the technique analysis it has been established that the sketch representing the evangelist Mark has been painted by another artist, probably, by his student F. Konovaliuk. Based on this it has been assumed that sketches had a false date and this date has been precised: 1940 to 1960 instead of the beginning of the 20th century.

Secondly, we have established the nature of co-authorship based on other icons from the Pokrovsky Church in Priorka; conclusions of two authors in the icons of evangelists have been made in the same way based on the overall study and analysis of evangelist images, that is, both the nature of the preparatory drawing and the paint layer itself (stylistic features, coloration, form representation, painting technique). We have determined differences in the building of composition and picture as well as in the level of execution; the analysis of the painting style of I. Yizhakevych and unknown artist, his co-author, has been also made.

Results of study will become useful for further studies of works of I. Yizhakevych, including for formation of catalogues which would include attributed works of the artist that are of great relevance now.

Key words: works of I. Yizhakevych, icon painting, attribution, evangelists, Pokrovsky Church in Priorka, Pokrovsky Church in Podil, co-authorship.

Постановка проблеми. Останнім часом науковці почали звертати увагу на сакральні твори українських художників, створені ними в радянський період. Особливе місце в цій темі займає іконопис I. Їжакевича в київських храмах (Покрови Пресвятої Богородиці на Пріорці, Свято-Макарівський на Татарці, Свято-Покровський на Подолі), що припадає на період 1940-1960 рр. На жаль, через довгий період часу, протягом якого іконопис в означених храмах лишався поза увагою дослідників, маємо велику кількість протиріч та шаблонних суджень, на які іноді спираються сучасні науковці.

Так, орієнтуючись на нечисленні джерела та не проводячи грунтовних досліджень, пензлю I. Їжакевича часто приписують твори, які мають невисокий професійний рівень. Нерідко в спробах атрибуції ікон I. Їжакевича спостерігаємо помилковість у визначені авторства мистця та його учня (Ф. Коновалюка), з яким вони тісно співпрацювали протягом другої половини творчого життя іконописця.

Це свідчить про недостатньо глибокий ступінь аналізу іконописної спадщини I. Їжакевича радянського періоду й доводить необхідність комплексного дослідження - як архівних матеріалів, так і самих пам'яток, $з$ точки зору стилістики, техніки виконання, технологічних особливостей та стану збереженості. Лише на основі поєднання мистецтвознавчих та реставраційних досліджень можна 3 упевненістю дати наукове обгрунтування питань атрибуції даних пам'яток, визначити техніко-технологічні особливості та сліди їх побутування. Також це допоможе вирішити важливе питання: розрізнення іконописних творів, що повністю належать пензлю І. Їжакевича; тих, які створеніним у співавторстві, а також творів інших іконописців.
Аналіз досліджень. Серед останніх досліджень іконописного спадку I. Їжакевича періоду 1940-1960 рр. переважають розвідки, спрямовані на виявлення в храмах Києва досі не відомих широкому загалу ікон I. Їжакевича. Так, дослідження О. Сторчай базуються на вивченні та аналізі архівних джерел. Дослідниця вперше опублікувала та структурувала окремі матеріали 3 архівів Центрального державного архіву музею діячів літератури та мистецтв України (надалі - ЦДАМЛМ) та Інституту рукопису Національної бібліотеки України В. І. Вернадського НАН України (ІР ЦНБУ). О. Сторчай також наголошує на недостатній кількості грунтовних досліджень творчості I. Їжакевича (Сторчай, 2018a), (Сторчай, 2018b).

Ширше висвітленою $€$ тема сакрального живопису I. Їжакевича в храмах Києво-Печерської Лаври. Зокрема, дослідженнями розписів та викладацької роботи I. Їжакевича у Лаврській іконописній школі займались такі науковці, як В. Шиденко (Шиденко, 2008), О. Пітателева (Пітателева, 2019), В. Литвиненко (Литвиненко, 2007).

Важливим для підготовки цієї статті джерелом $\epsilon$ одне 3 перших досліджень, присвячених Покровському храму на Пріорці, де, серед інших авторів, основний мистецтвознавчий аналіз ікон I. Їжакевича виконала О. Лопухіна (Пилипчук, та ін., 2016).

Актуальним для нашої теми $є$ стаття та монографія І. Дундяк; дослідниця грунтовно розкриває тему латентного існування сакрального живопису в радянський період українського мистецтва. Також I. Дундяк зачіпає важливу для іконописного спадку I. Їжакевича тему - поновлення зруйнованих під час більшовицької революції та Другої світової війни розписів, що активно застосовувалось ще за радянських часів. На жаль, і досі цим «методом» зловживають при реставрації 
храмових стінописів по всій Україні, і є чимало прикладів повного знищення автентичних розписів I. Їжакевича. Так, I. Дундяк згадує «Козацькі могили» (розписи церкви-меморіалу св. Георгія Переможця в с. Пряшева Рівненської області) та поліхромію церкви Покрови на Пріорці (Дундяк, 2016), (Дундяк, 2019).

Схожу тему (поновлення стінописів I. Їжакевича) побіжно висвітлює в своїй розвідці Н. Брей (Брей, 2019:181). Дослідниця, спираючись на інтернет джерела, описує історію розписів І. Їжакевичем Свято-Троїцького кафедрального собору (м. Дніпро). Загалом, ми погоджуємось 3 Н. Брей стосовно того, що поновленням 50-х рр. було сильно зіпсовано розписи I. Їжакевича поч. XX ст. На жаль, це автоматично унеможливлює використання стінописів Троїцького собору як еталонного порівняльного матеріалу при аналізі його спадщини (щоправда, не виключено, що під шарами поновлень $\epsilon$ залишки автентичних розписів I. Їжакевича). На цьому слід обов'язково наголосити, адже у ЗМІ поширюється думка про приналежність нинішніх розписів пензлю I. Їжакевича (Монументальные росписи..., 2011).

Вважаємо необхідним відзначити статтю А. Марченко, яку можна розглядати як вдалий приклад поєднання реставраційних та мистецтвознавчих методів дослідження. Викладено хід реставрації ікони І. Їжакевича (з Трапезного храму Києво-Печерської лаври) із застосуванням документальних джерел для реконструкції зображення; визначено ii техніко-технологічні особливості (Марченко, 2015). Фактично, публікація А. Марченко є першою, де висвітлений технікотехнологічний аспект ікони І. Їжакевича. На нашу думку, подальша розробка даного напряму досліджень $\epsilon$ перспективною у сенсі з'ясування притаманних творчості І. Їжакевича рис підготовчого малюнку, авторської живописної манери, палітри, а також особливостей основ та грунтів - i врештірешт, можливості уточнення атрибуції творів, що приписуються пензлю мистця. 3 іншого боку, виявлення корпусу творів I. Їжакевича у діючих храмах необхідно пов'язати зі встановленням їх нинішнього стану збереженості: це зможе справити позитивний вплив на проблему їх подальшого зберігання та застосування наукового підходу під час їх реставрації.

Окремо варто виділити дослідження Н. Кочережка, який є родичем I. Їжакевича, а отже, інформація подана ним, має значну цінність (Кочережко, 2010).

Підсумовуючи, зазначимо, що через значну кількість розвідок, присвячених творчості І. Їжаке- вича, та доволі відоме ім'я іконописця, в суспільстві складається стереотипна думка, що творчість мистця достатньо вивчена. Проте насправді більшість наявних розвідок лише частково висвітлюють існуючі проблеми. Серед них $є$ біографічні відомості, мистецтвознавчі та архівні дослідження, a також незначна кількість каталогів 3 портретами, пейзажами та ілюстраціями, виданими ще за радянських часів. Однак, майже зовсім не знаходимо техніко-технологічних досліджень, що наразі $\epsilon$ конче необхідними, як вже було зазначено вище.

Мета статті - дослідити техніко-технологічні особливості ікон чотирьох євангелістів 3 Покровського храму на Пріорці; проаналізувати манеру виконання головних та другорядних ділянок зображення; провести порівняльний аналіз 3 зображеннями євангелістів зі Свято-Покровської Подільської церкви, а також 3 іконами Свято-Макарівської церкви. Відрізнити авторські частини живопису від неавторських та виконаних в співавторстві; визначити відмінності авторської манери I. Їжакевича. На основі зібраних даних виконати атрибуцію ікон. Дослідити та сформулювати особливості іконопису I. Їжакевича в Покровській церкві на Пріорці (1943-1945).

Виклад основного матеріалу. У 1943-1945 pp. під час Другої Світової війни І. Їжакевичем було створено ікони для Церкви Покрови на Пріорці (Пилипчук, та ін., 2016:20). На жаль, більшість 3 них не мають підпису з лицевого боку. Наразі через те, що ікони знаходяться в діючому храмі, перевірити наявність підписів зі зворотного боку також немає можливості. Однак, під час попередніх досліджень нами було виявлено підпис I. C. Їжакевича зі зворотного боку ікони «Покрова Пресвятої Богородиці» 3 цього храму, який підтверджує дату створення ікони - 1943 р. (Шашкова, 2017). Також, за свідченням О. Лопухіної дослідником Д. Назаренком на задній стороні жертовника було помічено табличку з написом, що підтверджує авторство І. Їжакевича в трьох іконах, що розміщені в ньому: «Розп'яття», «Моління про чашу» та «Різдво» (Пилипчук, та ін., 2016:24)

Попередньо, за допомогою аналізу технікотехнологічних особливостей та живописної манери іконописця, авторство І. Їжакевича було встановлено в таких іконах церкви на Пріорці як: «Богоматір з Немовлям», «Спас на престолі», «Преображення Господнє», «Всіх скорботних Радість», «Покрова Пресвятої Богородиці» та ін. Майже в кожній з цих ікон було досліджено авторські правки та ділянки, що було доручено виконати учневі іконописця. Останні суттєво поступаються живопису I. Їжакевича. Загалом живописна 
складова ікон церкви на Пріорці має неоднорідний характер, що пояснюється умовами праці та нестачею необхідних матеріалів під час Другої світової війни (Так, було з'ясовано, що майже всі ікони I. Їжакевича в іконостасі виконані на фанері, в більшості з них відсутня паволока або в якості паволоки було застосовано марлеву тканину) (Шашкова, 2019).

Особливо чітке уявлення про такі особливості ікон $з$ церкви на Пріорці ми отримали після порівняння їх 3 іконами Свято-Макарівської церкви, що були створені іконописцем пізніше, у 1947 p. За цілісністю живописної манери, міцним академічним малюнком, пізнаванністю авторського почерку I. Їжакевича, означені ікони були віднесені нами до еталонних ікон мистця. Також, на відміну від ікон церкви на Пріорці, основою ікон Макарівської церкви є металеві пластини. Ймовірно, саме через це, а також через дотримання технології іконопису та перебування в кіотах вони гарно зберіглись. (Проте, це не стосується ікон іконостасу, що не належать пензлю І. Їжакевича вони зберіглися значно гірше).

Необхідно зазначити, що іконостас Церкви Покрови на Пріорці складається 3 трьох приділів: центральний присвячений Покрові Пресвятої Богородиці, лівий - святому Миколаю, правий святим великомученикам Георгію Переможцю та Димитрію Солунському. В кожній окремій частині $\epsilon$ Царські ворота, в яких розміщено ікони із зображенням чотирьох євангелістів, над воротами ікону «Таємна Вечеря», обабіч воріт - ікони Богоматері та Ісуса Христа.

В центральній частині іконостасу І. Їжакевичем виконані ікони «Преображення Господнє», обабіч воріт відповідно - «Богоматір з Немовлям» та «Спас на престолі», справа від них - храмова ікона «Покрова», над воротами - «Таємна вечеря», у воротах - ікони із зображенням чотирьох євангелістів, що досліджуються в даній статті. Також авторство I. Їжакевича впізнається в іконі «Святий Миколай» 3 лівого приділу; в правому приділі усі ікони написані іншим художником. Отже, ікони лівого (окрім Миколая) та правого приділів, за аналізом живописної манери - не належать пензлю І. Їжакевича та, за нашими спостереженнями, виконані різними іконописцями не дуже високого професійного рівня.

В іконах євангелістів центральної частини, як і в більшості одночасних їм ікон з церкви на Пріорці, як було зазначено вище, помічена неоднорідність живописної манери та малюнку. Однак, на відміну від інших ікон, композиція зображень євангелістів значно відрізняється. В наведених вище іконах церкви на Пріорці композиційне рішення $є$ цілісним, тобто створеним згідно єдиного авторського задуму, в якому пізнається творче мислення І. Їжакевича. Композиція ж ікон «Євангелісти» містить в собі два зовсім протилежні підходи. Так, верхня частина - лики євангелістів - створена I. Їжакевичем, але у нижній ми вбачаємо спробу наслідування однойменних розписів 3 парусів Володимирського собору (рис. 1, $3,4,5)$. За нашими спостереженнями, творчості I. Їжакевича не притаманне копіювання чи інтерпретація популярних на період початку XX ст. зразків з Володимирського собору (у кін. XIX на поч. XX ст. наслідування їх було досить розповсюдженим явищем).

У Покровському храмі нам вдалося встановити ряд ікон, виконаних за схожим принципом: I. Їжакевичем виконувались центральні фігури та найбільш складні й відповідальні ділянки зображення, учнем - другорядні постаті. Однак, як зазначалось вище, ці ікони більш цілісні, бо виконані згідно попереднього задуму I. Їжакевича. До того ж в окремих іконах I. Їжакевич частково або повністю доопрацьовував ту частину роботи, яку виконав учень, що робить ціліснішим сприйняття живописної виразності. До таких ікон відносимо: «Преображення Господнє», «Всіх скорботних Радість», «Покрова Пресвятої Богородиці» (на дерев'яній основі).

Задля розв'язання питання співавторства, нами було проведено дослідження ікон євангелістів за допомогою фотофіксації в інфрачервоному випромінюванні (рис. 1, 3, 4, 5). За його результатами 3'ясовано, що малюнок було нанесено поверх білого грунту за допомогою накресленої сітки. Таким методом користуються для того, щоб перенести малюнок з ескізу на необхідну поверхню (зазвичай збільшуючи його). За силою натиску на олівець означений малюнок видається не характерним для I. Їжакевича. Всі лінії, навіть допоміжні лінії сітки, є занадто жорстко наведені, що може свідчити про непевність виконавця, відсутність вільного творчого процесу та перенесення вже готового зразка. Також, зважаючи на незначний розмір (34×21 см), припускаємо, із самого початку ці ікони, за домовленістю, мав би виконати учень. Тож, підготовчий малюнок міг бути виконаний іншим іконописцем, ймовірно, учнем I. Їжакевича.

Дослідження за допомогою макрофотозйомки та ІЧ променях підтвердило припущення стосовно особливостей живопису ікон - суттєву відмінність між верхньою та нижньою частинами. Нижня частина написана тонким шаром, неврівноваженими яскравими або, навпаки, «брудними» кольо- 


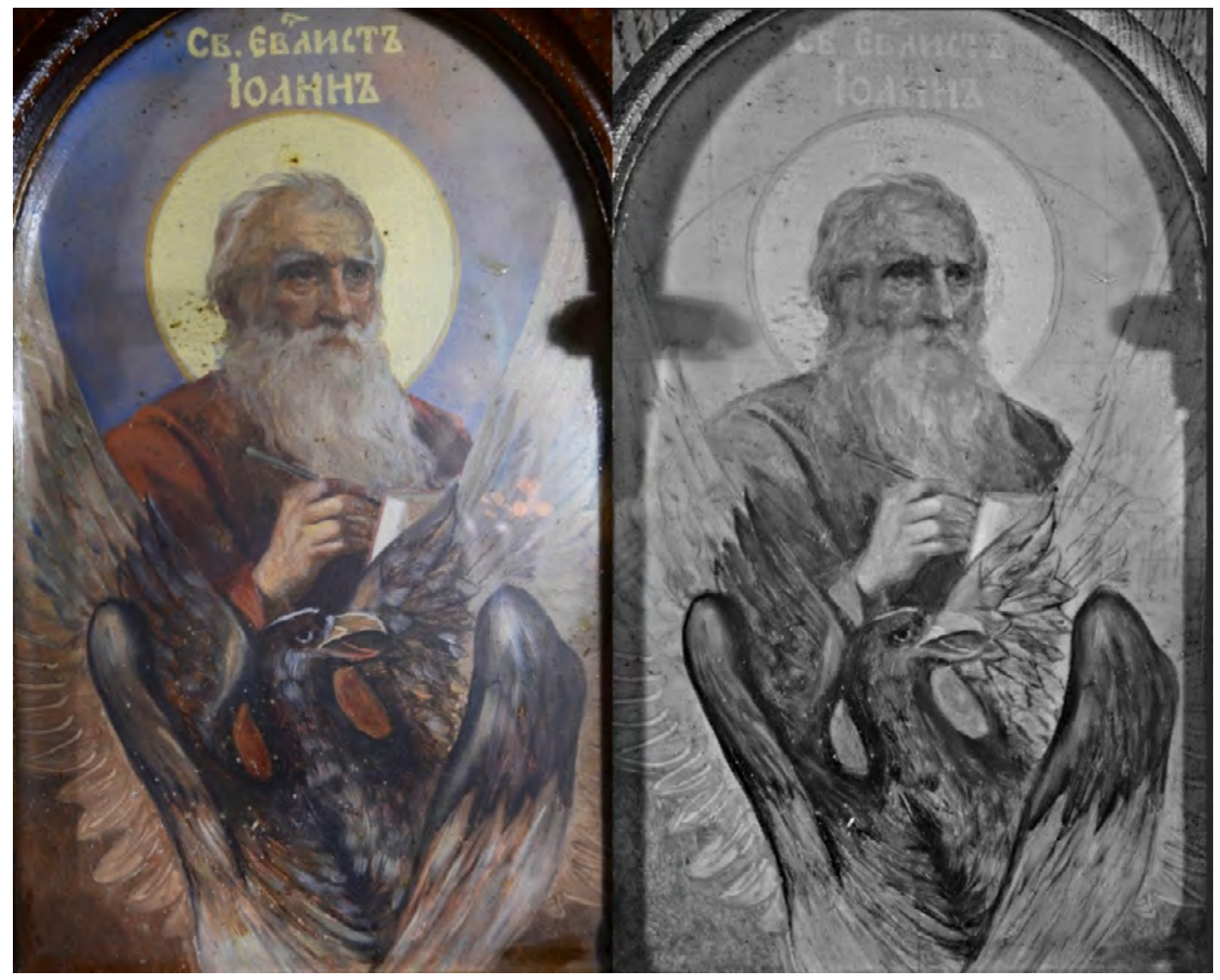

Рис. 1. Св. свангеліст Іван. Зліва(а) -фото у видимому світлі. Справа(б) -у ІЧ випромінюванні

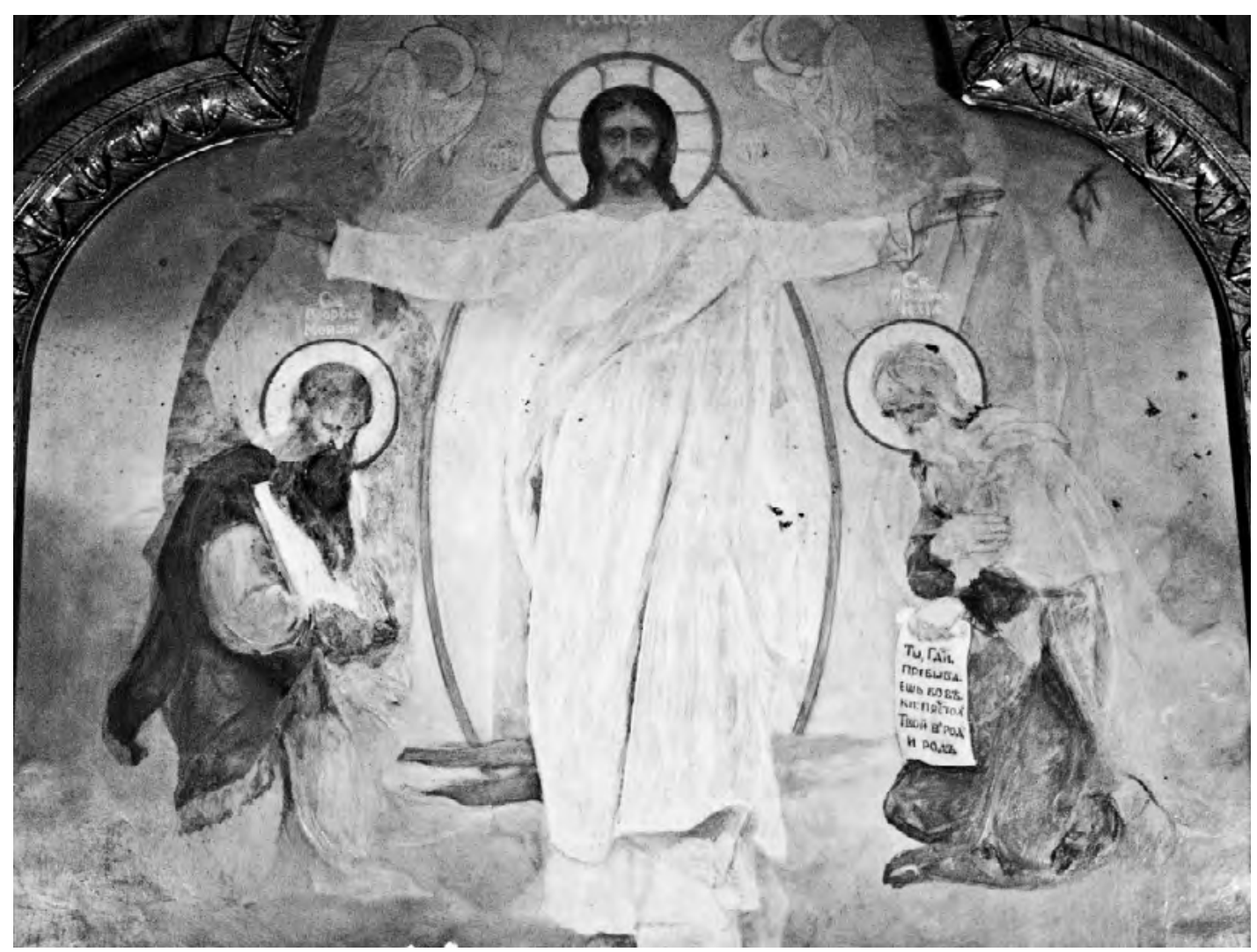

Рис. 2. Ікона «Преображення Господнє» (фрагмент). Авторсыкі правки постатей пророків та Ісуса (фото в IЧ випромінюванні) 
Шашкова А. Проблематика атриьуції ікон I. С. Їжакевича “Євангелісти” ...

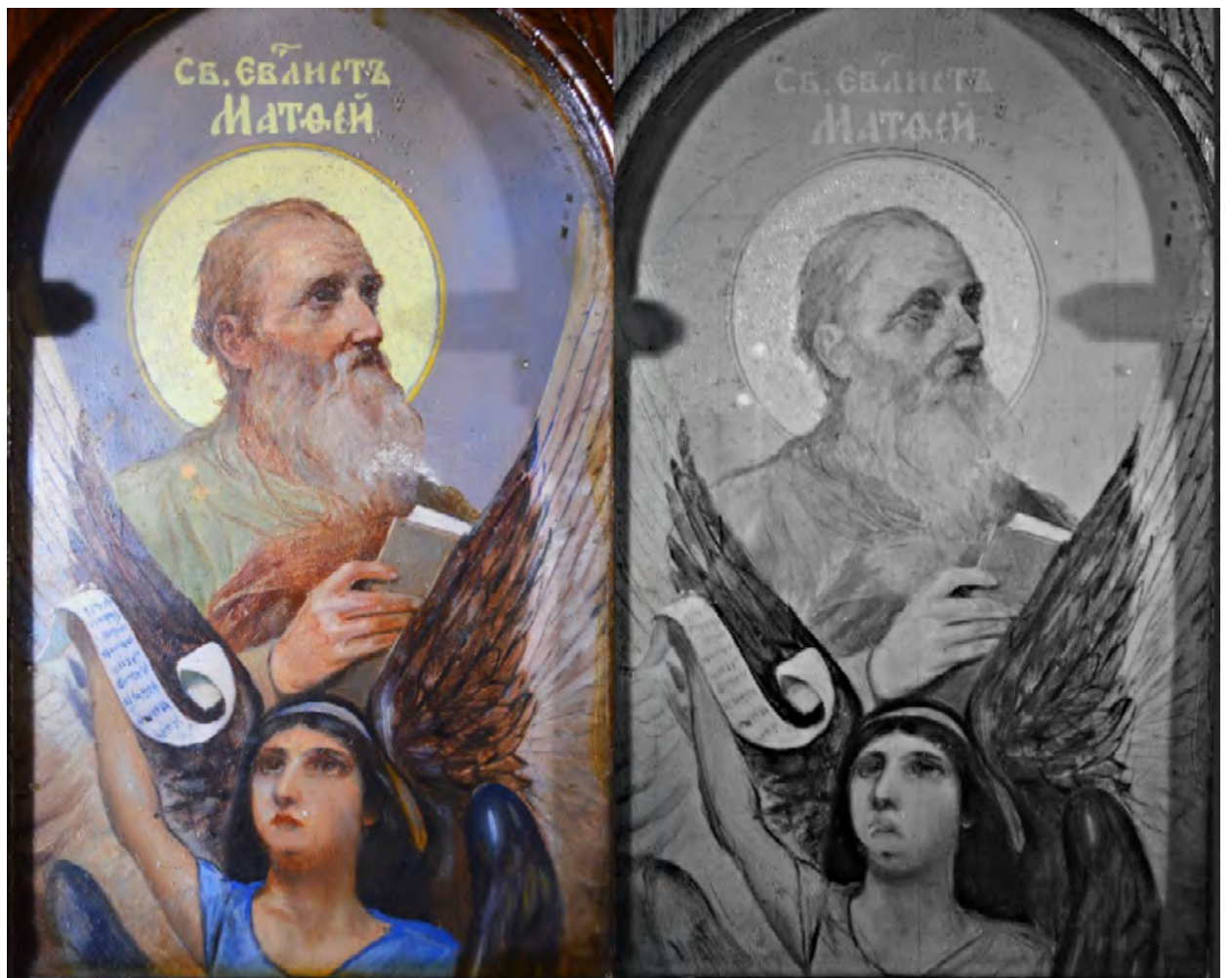

Рис. 3. Св. євангеліст Матвій. Зліва (а) - фото у видимому світлі, справа (б) -у ІЧ випромінюванні

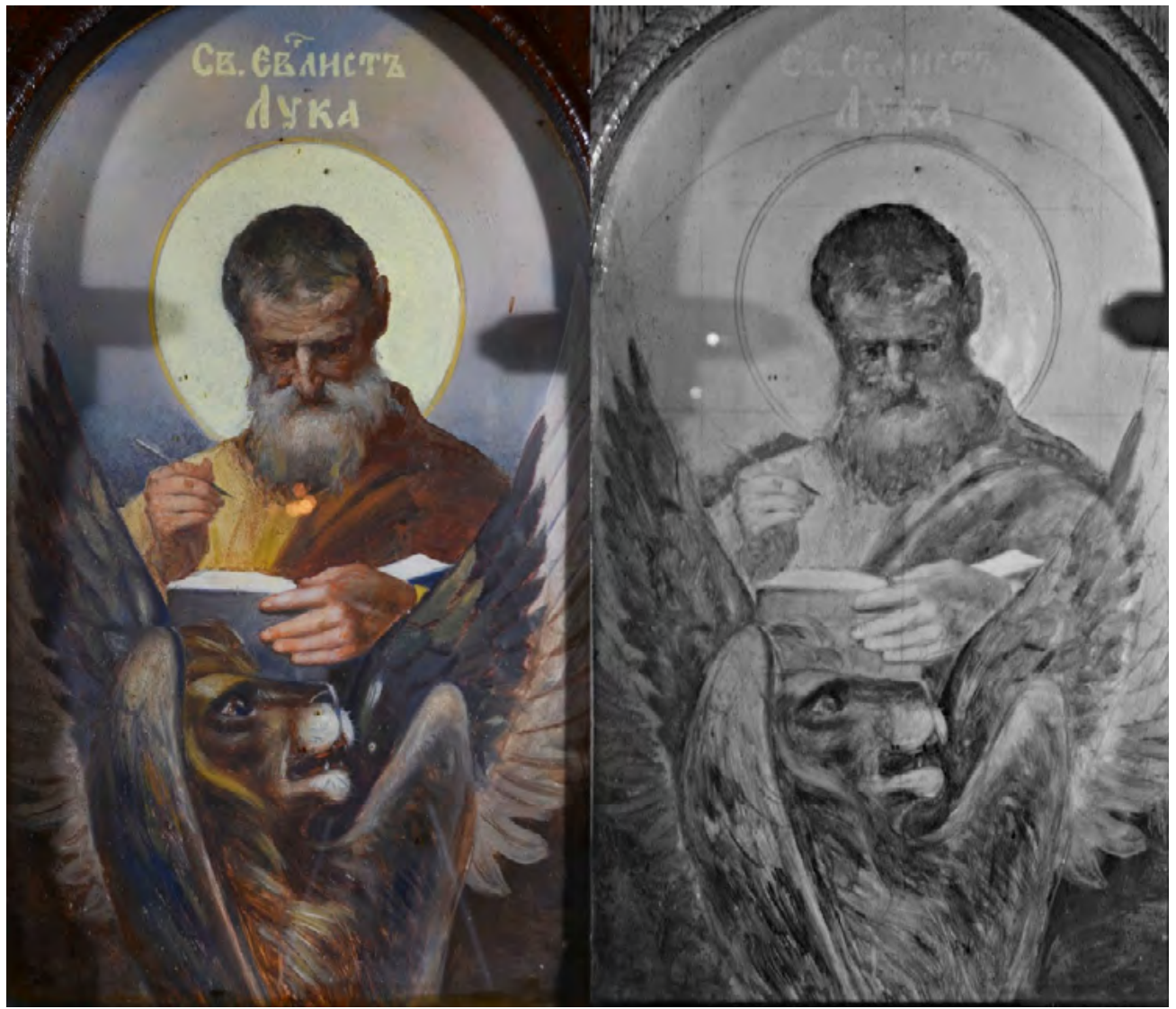

Рис. 4. Св. свангеліст Лука. Зліва (а) -фото у видимому світлі, справа (б) - у ІЧ випромінюванні 
рами, що не гармоніюють один 3 одним. Верхня має більше нашарувань, крізь неї майже не проглядається грубий малюнок олівцем, що наявний під живописом нижньої частини. На нашу думку, це пояснюється виявленими під час дослідження правками, які ущільнили живописний шар, a, також, ймовірно, були виконані по наново загрунтованому попередньому зображенню. Через це, напевно, підготовчий малюнок олівцем в ІЧ променях не прослідковується. Однак, під остаточним варіантом зображень в верхніх частинах ікон (голови євангелістів), було знайдено малюнок м'яким олівцем (рис. 1б). Саме такий малюнок найчастіше зустрічається як підготовчий в іконах, написаних I. Їжакевичем.

Також, за нашими спостереженнями колорит нижньої частини зображення відрізняється від колориту ділянок, створених, ймовірно, учнем I. Їжакевича Ф. Коновалюком в перерахованих нами вище іконах. За сукупним аналізом наведених ділянок та пейзажів Ф. Коновалюка, можна зробити висновки, що палітра цього учня I. Їжакевича більш виважена, кольори гармоніюють між собою. Тобто, найймовірніше, ікони «Свангелісти» написані не Ф. Коновалюком, а одним 3 менш вправних іконописців, які працювали над іншими іконами іконостасу.

Отже, кому належить живопис під правками та в нижній частині зображення (символи євангелістів) - наразі неможливо впевнено стверджувати. За однією версією, перший шар живопису разом 3 нижньою частиною був написаний іншим іконописцем (причому не обов'язково учнем I. Їжакевича), і вже пізніше I. Їжакевичем було виконано правки голів євангелістів. За іншою - правки в верхній частині ікон були виконані І. Їжакевичем поверх власного живопису (при цьому нижня частина була виконана іншим іконописцем). Подібні авторські правки вже досліджувались нами в храмі на Пріорці (рис. 2).

Проте, у досліджених нами раніше іконах попередній живопис гарно проглядається крізь новий шар, так що можна з впевненістю стверджувати, що за всіма наявними ознаками він належить I. Їжакевичу. В даному випадку, ймовірно, через те, що попередній живопис було загрунтовано перед створенням поверх нього нового - малюнок не проглядається. Тож, спираючись на те, що іконописця зовсім не влаштовував перший варіант, на нашу думку, більш вірогідною є перша версія.

В іконах «Св. євангеліст Матвій» та «Св. євангеліст Іван», вже поверх загрунтованого першого зображення, бачимо незначну зміну положення голови святих, що можна віднести до авторських правок І. Їжакевича, пов'язаних із пошуком оптимального рішення (рис. 1б, 3б). Малюнок змінено, проте попередній варіант добре проглядається крізь живопис. Як вже було з'ясовано нами, подібні правки характерні для ікон І. Їжакевича в церкві на Пріорці (Шашкова, 2019). Крім важких умов праці, на їх появу вплинула також експресивна жива манера іконописця.

А втім, з усією відповідальністю можна стверджувати, що остаточний живописний варіант голів євангелістів створений I. Їжакевичем. В рисах обличь святих пізнаються характерні для I. Іжакевича типи. Наприклад, образ євангеліста Луки схожий на портретний образ євангеліста Матвія з парусів Свято-Покровської Подільської церкви. Цікаво, що, за свідченням В О. Гунька, прообразом св. Матвія став батько I. Їжакевича: «Батько художника відтворений в образі євангеліста Матвія на розписах Покровської церкви на Київському Подолі. А прообразом євангеліста Луки слугував отець Мараховський - родич художника, священник із його рідного села Вишнопіль» (Гунько, 2012). Також, за нашими спостереженнями, образ Матвія 3 храму на Пріорці візуально схожий на портрет Івана з храму на Подолі.

Голови євангелістів написані у властивій іконописцю манері. Зображення мають закінчений вигляд, однак, при близькому вивченні, глядача вражає, наскільки швидко та невимушено було їх написано: напіврідкою фарбою, віртуозно - фактично в один прийом. Перед початком роботи І. Іжакевич робив, як правило, малюнок м'яким матеріалом, в якому відтворював необхідний образ. Наступним етапом роботи над іконами «Свангелісти» був гризайльний підмальовок брунатного кольору.

Невеликі за розміром твори І. Їжакевич писав майже за один сеанс. В творах більшого розміру другорядні ділянки зображення писались в один прийом, до головних фрагментів I. Їжакевич повертався знову, щоб удосконалити їх. В іконах «Свангелісти» головна частина роботи була виконана в гризайльному прописі. Далі, по тільки-но зробленому гризайльному пропису, за допомогою сірувато-блакитних, рожевих та вохристих кольорів було пророблено та завершено ділянки по світах. Тіньові ділянки лишились змодельованими майже лише гризайльним прописом (рис. 4). У цьому вбачаємо відлуння системи академічного живопису XIX ст.

I хоча означені фрагменти ікон «Свангелісти» виглядають менш завершеними, проте при порівнянні $з$ еталонними творами I. Їжакевича у них легше визначити етапність виконання роботи над живописом. До того ж, подібна живописна манера 
Шашкова А. Проблематика атриьуції ікон I. С. Їжакевича «Євангелісти” ...

відрізняє портрети євангелістів від інших невеликих ікон іконостасу, які виконані в більш типовій, традиційній манері іконопису. Отже, окрім високого професійного рівня, іконописні образи I. Їжакевича, завдячуючи вільній манері живопису, мають напрочуд живий, безпосередній характер.

Сприяє щирості образів й рідкісний талант іконописця: за свідченням вже згаданого вище О. Гунька, I. Їжакевич, маючи непересічну зорову пам'ять, відтворював в образах святих добре знайомих йому 3 дитинства людей (Гунько, 2012). Отже, стає зрозумілим, чому в образах святих I. Їжакевича ми впізнаємо старовинні українські типи. Подібну теплоту та наближеність до звичайних людей спостерігаємо також в бароковій українській іконі. У цьому творчий доробок I. Їжакевича наслідує українську іконописну традицію.

Повертаючись до живописних особливостей досліджуваних ікон, слід зазначити, що образ євангеліста Марка дещо відрізняється від інших (рис. 5). Колорит, що застосовано тут, менш виважений, - кольори яскраві, однак не гармонізовані по відношенню до тла та один до одного. Саме через це, на перший погляд, видається, що портрет Марка написаний іншим іконописцем. А втім, за аналізом живописної манери, характеру нанесення мазків припускаємо, що зображення Марка також написане I. Їжакевичем. До того ж, на світлинах в інфрачервоному випромінюванні в зображенні Марка проглядається характерний для I. Їжакевича малюнок м'яким матеріалом. Крім того, іконописцю необхідно було підлаштовуватись до яскравого колориту нижньої частини зображення.

Припускаємо також, що саме руки Марка, єдині серед усіх рук євангелістів, написані I. Їжакевичем. Руки створено в один сеанс, що видає їх дещо недоопрацьований вигляд. Проте, вільний характер ведення пропису, в якому одразу виконується і малюнок, і живописне рішення, контрастує $з$ усереднено-типовою, досить скутою манерою авторів інших ікон цього іконостасу та видає манеру I. Їжакевича. Очевидно, у даному випадку майстер написав руки Марка замість іншого іконописця, який не встигав виконати свій обсяг роботи, а дуже вільний характер письма пояснюється поспіхом, що, однак, не вплинуло на якість живопису й малюнку.

Очевидно, саме поспіхом можна пояснити невідповідність образів двох євангелістів (які упізнаються за їх символами в нижній частині зображення) до написів їхніх імен: символи Марка (лев) та Луки (тілець) переплутані. За

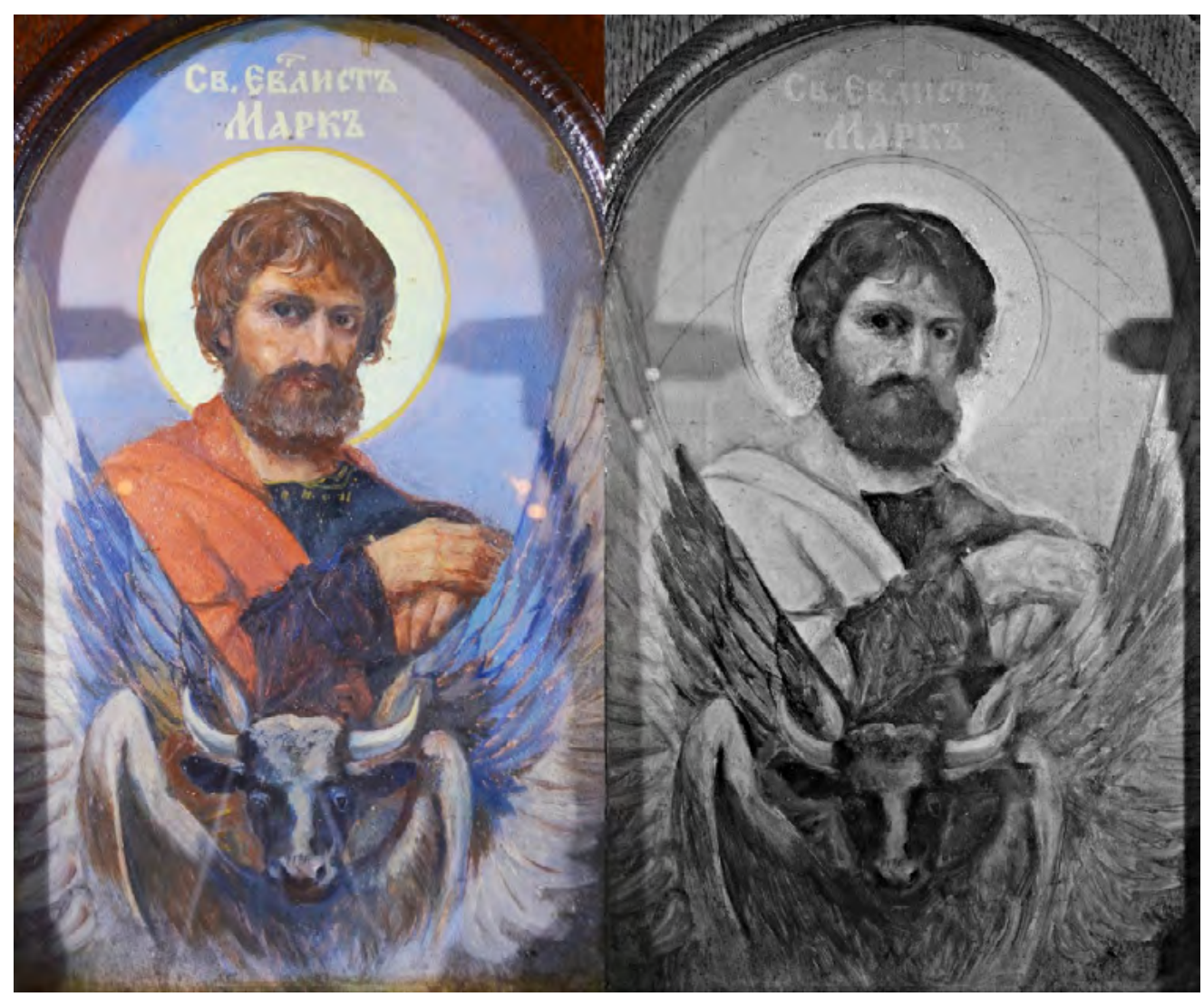

Рис. 5. Св. євангеліст Марк. Зліва (а) -фото у видимому світлі, справа (б) -у ІЧ випромінюванні 
нашим припущенням, написи створювались пізніше, i чомусь І. Їжакевич не контролював цей процес, адже подібна помилка для іконописця такого високого професійного рівня була б просто неможливою (рис. 4, 5).

В багатьох джерелах знаходимо інформацію, що помічником I. Їжакевича при створені ікон церкви Покрови Пресвятої Богородиці на Пріорці, а також Свято-Макарівської на Татарці та СвятоПокровської на Подолі міг бути Ф. З. Коновалюк. Відомості про їх спільну роботу в церкві Покрови Пресвятої Богородиці знаходимо в О. Лопухіної (Пилипчук, та ін., 2016:27), але для такого значного обсягу робіт могли запрошуватись й інші, менш вправні помічники, що й засвідчило дане дослідження.

За допомогою порівняльного аналізу з іконами Макарівської церкви на Татарці та Покровської Подільської церкви, що приписують І. Їжакевичу, було виявлено та проаналізовано три варіанти спільної праці над іконами вчителя та учня (учнів) або помічників.

До першого варіанту належать ікони, основна частина яких була написана I. Їжакевичем, а другорядна - довірена для написання учню/помічнику, що, як правило, наслідував протографи розписів Володимирського собору. Таких ікон зустрічаємо небагато. В другому - окремі фрагменти ікон (руки, тло) було доручено до виконання учневі/ помічнику під керівництвом I. Їжакевича.
В третьому варіанті - учневі/помічнику доручалось виконати другорядні постаті святих, або навіть усю нижню частину ікони; щоправда, в цьому випадку найчастіше I. Їжакевич їх доопрацьовував або майже повністю перероблював.

До другого та третього варіанту відносимо основну кількість ікон церкви Покрови на Пріорці. Натомість, в Свято-Макарівській церкві на Татарці ми не помітили ікон зі спільним авторством. Окрім п'яти ікон (розташованих поза іконостасом), що безумовно належать I. Їжакевичу, решта одночасних їм ікон виконана іншими іконописцями невисокого професійного рівня, причому протографом для більшості з них слугують образи з Володимирського собору.

В Свято-Покровській Подільській церкві I. Їжакевичем виконано чотири ікони із зображенням євангелістів, що розміщені на парусах; у них знайдено окремі ділянки, що ймовірно, за домовленістю, були виконанні Ф. Коновалюком (руки євангелістів Івана та Марка). В інших іконах храму взагалі не було помічено авторства I. Їжакевича.

Цікаво, що в ЦДАМЛМ зберігаються ескізи до образів євангелістів, які датуються початком ХХ століття.(ЦДАМЛМ Ф. 58. Оп. 1. Спр. 20). За нашим переконанням, оскільки в означених ескізах також прослідковуються ознаки співавторства, вони були виконані пізніше, а саме в період 1940-1960-х рр. При цьому не виключено, що взірцем для ескізів могли слугувати більш ранні

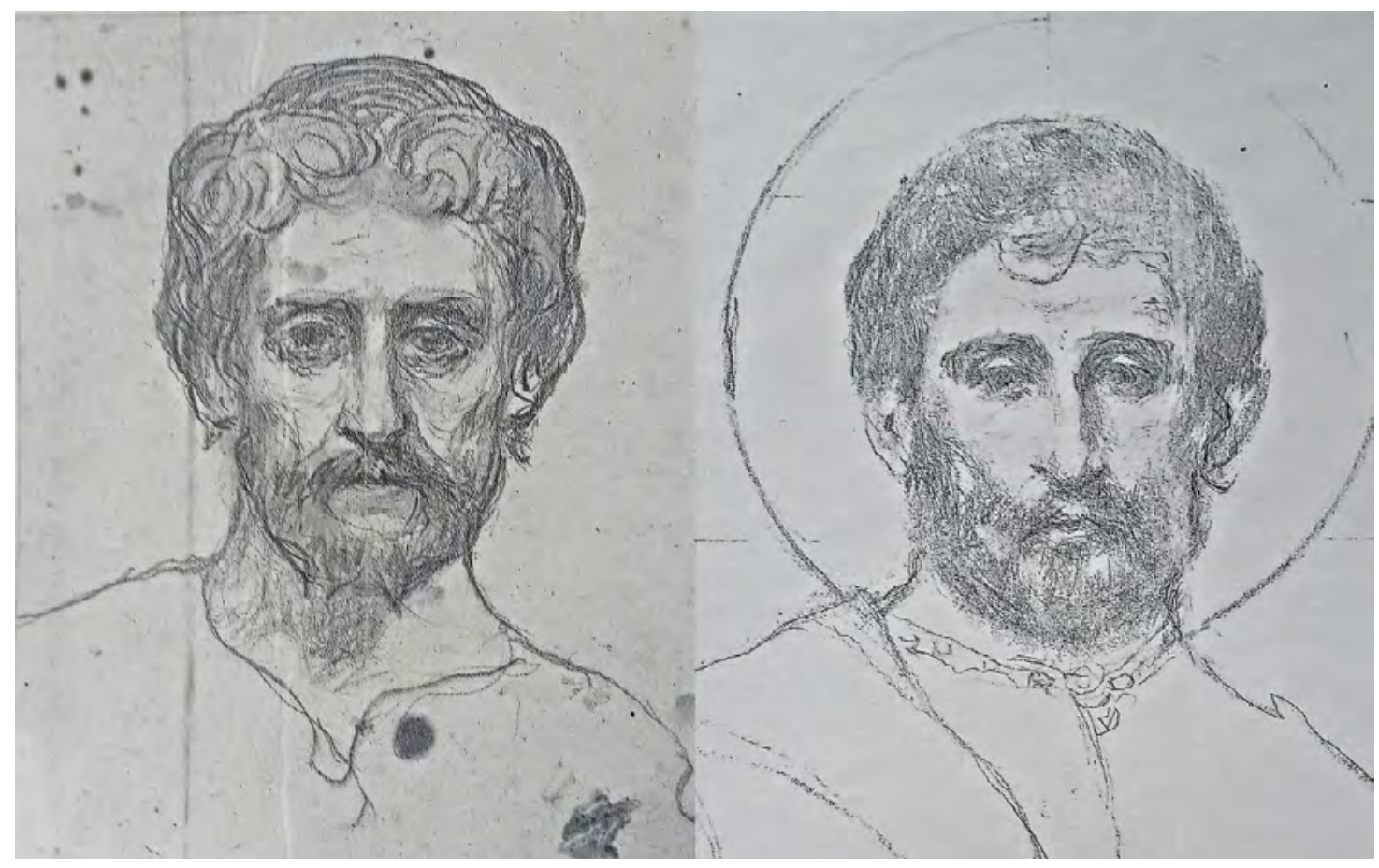

Рис. 6. Св. свангеліст Марк. Зліва(а) - ескіз поч. ХХ ст., справа(б) - фрагмент ескізу поч. ХХ ст. (авт. - сер. ХХ ст.) (ЦДАМЛМ) 
малюнки I. Їжакевича. Оскільки ікони «Свангелісти» 3 Покровського Подільського храму майже 3 точністю повторюють ескізи з ЦДАМЛМ, припускаємо, що їх було створено саме для ікон церкви на Подолі.

Показово, що ознаки співпраці I. Їжакевича 3 Ф. Коновалюком особливо прослідковуються в ескізі до святого євангеліста Марка (рис. 6б). Так, наприклад, за неподібною до I. Їжакевича манерою та майстерністю виконання малюнку, зокрема, слабким володінням анатомією людини, ескіз «Св. Свангеліст Марк» було віднесено нами до робіт Ф. Коновалюка. Малюнок виконано непевними переривчастими штрихами, скрізь однаковими за силою натиску олівця, що не характерно для I. Їжакевича. Особливо це підтверджується при порівнянні означеного ескізу з іншим ескізом I. Їжакевича до образу євангеліста Марка, що датується початком XX століття 3 цього ж архіву (ЦДАМЛМ Ф. 58. Оп. 1. Спр. 45)(мал. 6 а). В ньому, незважаючи на невеликий розмір зображення, ми бачимо, як за допомогою графічних засобів майстерно створюється форма.

Висновки. Застосовані методи комплексного дослідження дали змогу встановити, що ікони «Свангелісти» 3 церкви Покрови Пресвятої Богородиці було створено у 1943-1945 рр. Робота над іконами відбувалась у складні часи Другої світової війни, із застосуванням неякісних матеріалів й 3 великим поспіхом. Наявні на той час умови вплинули на методи ведення роботи над іконами.

Очевидно, ікони «Свангелісти» 3 самого початку мали бути виконані іншим іконописцем. Проте, в процесі роботи I. Їжакевичем були переписані голови євангелістів в верхній частині зображення. Також визначено, що остаточне зображення голів євангелістів, ймовірно, було написане по наново загрунтованому попередньому зображенню. Стилістика й манера виконання двох частин значно різняться.

До ознак живопису I. Їжакевича було віднесено: підготовчий малюнок м'яким матеріалом; майстерне моделювання форми в гризайльному прописі; для другорядних та незначних за розміром фрагментів - письмо напіврідкою фарбою 3 віртуозним завершенням майже в один прийом; при створенні головних - пропис в кілька прийомів, більш щільними фарбовими сумішами, 3 ретельною м'якою проробкою деталей. У манері I. Їжакевича прослідковується професійна впевненість, схильність до інтерпретації, творчі пошуки нових технічних живописних прийомів й одночасно - укоріненість у академічній традиції.

До ознак живопису іншого іконописця, що виконав зображення нижньої частини ікон, віднесено: підготовчий малюнок жорстким олівцем, анатомічно не вивірений, невисокого професійного рівня; гризайльний підмальовок; однаковий за рівнем проробки пропис як для головних, так i для другорядних частин; кольори або занадто відкриті, неврівноважені між собою, або подекуди «брудні». Також в усіх зазначених фрагментах, частково відтворені протографи В. Васнєцова 3 парусів Володимирського собору.

На основі порівняльного аналізу ікон, що приписують I. Їжакевичу, в церкві Покрови Пресвятої Богородиці на Пріорці, Свято-Макарівській церкві на Татарці та Свято-Покровській Подільській церкві на київському Подолі, було сформовано три типи взаємодії мистця та його учнів/ помічників при роботі над іконами в період творчості І. Їжакевича у 1940 - 1960-х pp.

Визначено, що в церкві на Пріорці більшість ікон виконано у співпраці, однак за творчим задумом та при керівництві I. Їжакевича. На противагу цьому, ікони «Свангелісти» вирізняються серед інших розрізненим композиційним рішенням, яке ми пояснюємо тим, що, ймовірно, ікони були виконані іншим, менш професійним, іконописцем, який працював окремо від І. Їжакевича. Ймовірно, саме цим іконописцем по завершенню роботи було невірно нанесено написи на ікони «Святий Євангеліст Марк» та «Святий Євангеліст Лука».

Висловлюємо подяку громадам Покровського та Макарівського храмів та їх настоятелям протоієреям Константину Пилипчуку та Владиславу Софійчуку за надану можливість проведення дослідження. Щиро дякуємо Цитовичу Володимиру Івановичу за допомогу в проведенні досліджень, фотографуванні у різних зонах спектру та консультації та Катерині Коваль за величезну допомогу при фотофіксації ікон.

\section{СПИСОК ВИКОРИСТАНИХ ДЖЕРЕЛ}

1. Брей Н. Сакральні розписи Івана Сидоровича Їжакевича в Скатеринославському Свято-Троїцькому соборі. Наукова атрибуиія творів мистецттва, експертиза та оцінка культурних иінностей: зб. матеріалів наук.-практ. конф. (м. Київ, НАККіМ, 24 - 25 жовтня 2019 р.). НАККіМ. Київ, 2019.С. 181-185.

2. Гунько О. Іван Їжакевич малював святих зі своїх рідних та односельців URL: http://gazeta.ua/articles/historynewspaper/_ivan-izhakevich-malyuvavsvyatih-zi-svoyih-ridnih-ta-odnoselciv/418853 (дата звернення 20.11.2020)

3. Дундяк I. М. Іван Їжакевич і церковне мистецтво України другої половини XX ст. Народознавчі зошити. 2016. № 5. С. 1095-1101. 
4. Дундяк I. М. Українське церковне малярство другої половини XX - початку XXI століть: дис. ... д-ра мистецтвознавства : 26.00.01. Івано-Франківськ, 2019. 484 с.

5. Кочережко Н. Славний майстер київського іконопису. До 145-річчя від дня народження Івана Їжакевича. Bidлуння віків. 2010. №. 12. С. 58-61.

6. Литвиненко Я. Втілення програми всіх святих у художньому оформленні Всіхсвятського храму. Живопис трьох століть. Лаврський альманах. 2007. № 17. С. 59-72.

7. Марченко А. Исследования и атрибуция иконы «Собор 12 Апостолов» на медной основе начала ХХ века из Трапезной церкви Киево-Печерской Лавры. Экспертиза и атрибуция произведений изобразительного и декоративно-прикладного искусства: зб. материалов XVIII научной конференции. Москва: Изд. Об-ния Магнум Арс., 2015. C. $246-251$.

8. Монументальные росписи Свято-Троицкого кафедрального собора в Днепропетровске. URL: http://eparhia.dp.ua/ novosti/monumentalnye-rospisi-svyato-troitskogo-kafedralnogo-sobora-v-dnepropetrovske/ (дата звернення 20.11.2020)

9. Пилипчук К., прот., Черный С., свящ., Лопухина Е. В., Хроненко И. В Покровская церковь на Приорке (к 110летию со дня основания). Исторический очерк. Киев: Изд. отдел Укр. Православной Церкви, 2016. 40 с.

10. Пітатєлєва О. Творчість І. С. Їжакевича. До питання зображення святителів у розписі Лаврської Трапезної. Церква-наука-суспільство: питання взаємодї: зб. матеріалів XVII Міжнародної наукової конференції.(м. Київ, НКПІКЗ, 28 травня - 1 червня 2019 р.). Київ, 2019. С. 107-111

11. Сторчай О. Подробиці з творчого життєпису Івана Їжакевича (за архівними джерелами). Студї̈ мистеитвознавчі. 2018. №4. С. 90-97.

12. Сторчай О. 3 листів Івана Їжакевича до Федора Коновалюка (1941 - 1961 роки): до 155-річчя від дня народження I. Їжакевича. Рукописна та книжкова спадщина України. 2018. №2 С. 479-526.

13. Архів ЦДАМЛМ Ф. 58. Оп. 1, Спр. 20.

14. Архів ЦДАМЛМ Ф. 58 , Оп. 1, Спр. 45.

15. Шашкова А. Живописна техніка ікон І. С. Їжакевича «Спас на престолі» та «Богоматір з немовлям» (Покровська Церква на Пріорці). Проблема авторських та неавторських поновлень. Украӥнська академія мистецтва: дослідницькі та науково-методичні праці. НАОМА. Київ, 2019. №28. С.170-179.

16. Шашкова. А. Іконописна спадщина I. С. Їжакевича: особливості техніки та реставрації (На прикладі ікони «Покрова Пресвятої Богородиці» з діючої Покровської церкви на Пріорці). Дипломна робота на здобуття кваліфікаційного рівня магістра. НАОМА. Київ, 2017. С. 45-52.

17. Шиденко В. Вибрані праці з історії Києво-Печерської Лаври. Київ: НКПІКЗ, Фенікс, 2008. 256 с.

\section{REFERENCES}

1. Brei N. Sakralni rozpysy Ivana Sydorovycha Yizhakevycha v Yekaterynoslavskomu Sviato-Troitskomu sobori. [Sacred painting of Ivan Sidorovich Izhakevych in the Cathedral of the Holy Trinity in Ekaterinoslav] Scientific attribution of works of art, examination and evaluation of cultural values: a coll. of materials of the scientific-practical conference (October 24-25, 2019). National Academy of Culture and Arts Management. Kyiv, 2019, pp. 181-185 [in Ukrainian].

2. Hunko O. Ivan Yizhakevych maliuvav sviatykh zi svoikh ridnykh ta odnoseltsiv [Ivan Izhakevych painted saints from his family and fellow villagers] URL: http://gazeta.ua/articles/history-newspaper/_ivan-izhakevich-malyuvavsvyatih-zi-svoyih-ridnih-ta-odnoselciv/418853 (date of application 20.11.2020) [in Ukrainian].

3. Dundiak I. M. Ivan Yizhakevych i tserkovne mystetstvo Ukrainy druhoi polovyny KhKh st. [Ivan Izhakevych and church art of Ukraine in the second half of the twentieth century]. Ethnographic notebooks. 2016, Nr.5, pp. 1095-1101 [in Ukrainian].

4. Dundiak I. M. Ukrainske tserkovne maliarstvo druhoi polovyny KhKh - pochatku KhKhI stolit [Ukrainian church painting of the second half of the XX - beginning of the XXI century]: dissertation for the title of Doctor of Arts: 26.00 .01 . Ivano-Frankivsk, 2019, 484 P. [in Ukrainian].

5. Kocherezhko N. Slavnyi maister kyivskoho ikonopysu. Do 145-richchia vid dnia narodzhennia Ivana Yizhakevycha [Glorious master of Kyiv icon painting. To the 145th anniversary of the birth of Ivan Izhakevych]. Echoes of the ages. 2010 , Nr. 12, pp. 58-61. [in Ukrainian].

6. Lytvynenko Ya. Vtilennia prohramy vsikh sviatykh u khudozhnomu oformlenni Vsikhsviatskoho khramu. Zhyvopys trokh stolit.[Implementation of the programs of all saints in the decoration of the temple of All Saints. Painting of three centuries] Lavra Almanac. 2007. Nr. 17, pp. 59-72. [in Ukrainian].

7. Marchenko A. Issledovaniya i atributsiya ikonyi «Sobor 12 Apostolov» na mednoy osnove nachala $\mathrm{HH}$ veka iz Trapeznoy tserkvi Kievo-Pecherskoy Lavryi. Ekspertiza i atributsiya proizvedeniy izobrazitelnogo i dekorativno-prikladnogo iskusstva [Research and attribution of the icons "Cathedral of the 12 Apostles" on a copper base of the early twentieth century from the Refectory Church of the Kyiv-Pechersk Lavra]. Examination and attribution of fine and decorative arts: a coll. of materials of the XVIII scientific conference. Publishing house of the Magnum Ars Association. Moscow, 2015, pp. 246-251. [in Russian].

8. Monumentalnyie rospisi Svyato-Troitskogo kafedralnogo sobora v Dnepropetrovske. [Monumental paintings of the Holy Trinity Cathedral in Dnepropetrovsk] URL: http://eparhia.dp.ua/novosti/monumentalnye-rospisi-svyato-troitskogo-kafedralnogo-sobora-v-dnepropetrovske/ (date of application 20.11.2020) [in Russian].

9. Pilipchuk K., prot., Chernyiy S., svyasch., Lopuhina E. V., Hronenko I. V Pokrovskaya tserkov na Priorke (k 110-letiyu so dnya osnovaniya). Istoricheskiy ocherk [Church of the Intercession on Priorka (to the 110th anniversary of its foundation). Historical sketch] Publishing Department of the Ukrainian Orthodox Church. Kyiv, 2016, 40 P. [in Russian]. 
10. Pitatielieva O. Tvorchist I. S. Yizhakevycha. Do pytannia zobrazhennia sviatyteliv u rozpysi Lavrskoi Trapeznoi. Tserkva-nauka-suspilstvo: pytannia vzaiemodii [Creativity of IS Izhakevich. On the question of the image of saints in the painting of the Lavra refectory]. Church-science-society: issues of interaction: coll. Proceedings of the XVII International Scientific Conference (Kyiv, National Kyiv-Pechersk Historical and Cultural Preserve, May 28 - June 1, 2019). Kyiv, 2019, pp. 107-111. [in Ukrainian].

11. Storchai O. Podrobytsi z tvorchoho zhyttiepysu Ivana Yizhakevycha (za arkhivnymy dzherelamy) [Details from the creative biography of Ivan Izhakevich (according to archival sources)]. Art studies. 2018, Nr.4, pp. 90-97. [in Ukrainian].

12. Storchai O. Z lystiv Ivana Yizhakevycha do Fedora Konovaliuka (1941 - 1961 roky): do 155-richchia vid dnia narodzhennia I. Yizhakevycha. [From Ivan Izhakevich's letters to Fedor Konovalyuk (1941 - 1961): to the 155th anniversary of I. Izhakevich's birth]. Manuscript and book heritage of Ukraine. 2018, Nr. 2, pp. 479-526. [in Ukrainian].

13. Central State Archives Museum of Literature and Arts of Ukraine. F. 58. Op. 1, Spr. 20 [Fund 58, Description 1, Case 45]

14. Central State Archives Museum of Literature and Arts of Ukraine. F. 58. Op. 1, Spr. 45 [Fund 58, Description 1, Case 45]

15. Shashkova A. Zhyvopysna tekhnika ikon I. S. Yizhakevycha «Spas na prestoli» ta «Bohomatir z nemovliam» (Pokrovska Tserkva na Priortsi). Problema avtorskykh ta neavtorskykh ponovlen. [Painting Technology of Icons "Christ Enthroned"and "Blessed Virgin Mary and Baby Jesus" (Pokrovsky Church in Priorka).Painted by Ivan S. Yizhakevych. Problem of Author and Non-Author Renewals]. Ukrainian Academy of Arts: research and scientific-methodical works. Kyiv, 2019, Nr. 28. pp.170-179. [in Ukrainian].

16. Shashkova. A. Ikonopysna spadshchyna I. S. Yizhakevycha: osoblyvosti tekhniky ta restavratsii (Na prykladi ikony «Pokrova Presviatoi Bohorodytsi» z diiuchoi Pokrovskoi tserkvy na Priortsi). [Icon-painting heritage of IS Izhakevich: features of technique and restoration (On the example of the icon "Protection of the Blessed Virgin Mary" from the current Church of the Intercession on the Priorka)] Thesis for a master's degree. National Academy of Fine Arts and Architecture. Kyiv, 2017, pp. 45-52. [in Ukrainian].

17. Shydenko V. Vybrani pratsi z istorii Kyievo-Pecherskoi Lavry. [Selected works on the history of the Kiev-Pechersk Lavra] National Kyiv-Pechersk Historical and Cultural Preserve. Feniks, Kyiv, 2008, 256 P. [in Ukrainian]. 